\title{
Mulige biomarkører for Alzheimers sykdom
}

Lipidverdier i blodet synker flere år før hukommelsessvikt kan spores med psykologiske tester.

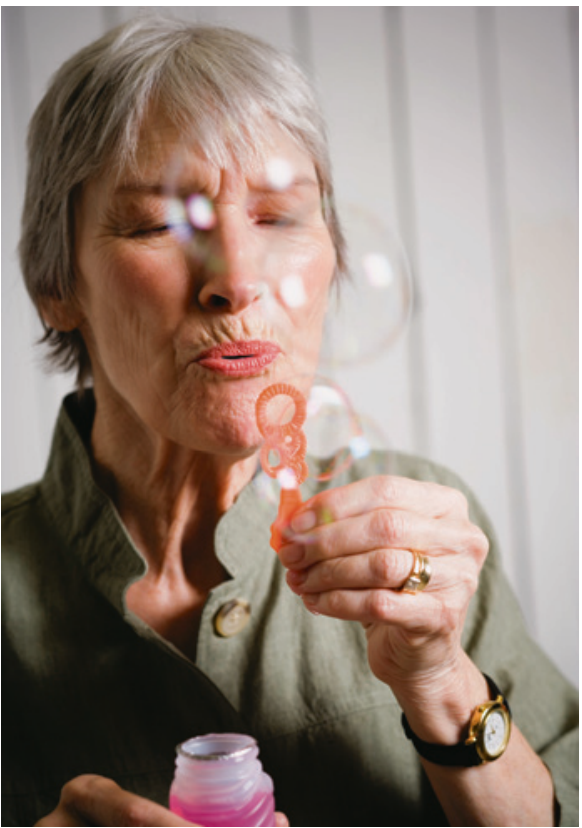

Illustrasjonsfoto: Pixtal/NTB Scanpix
Tidlig diagnostisering av Alzheimers sykdom er vanskelig. Biomarkører i blodprøver kunne kanskje - i motsetning til prøver av cerebrospinalvæske og MR-avbildning av hjernen - brukes som screeningtest. Nå foreligger en lipidomanalyse av blodet til 525 eldre personer som antyder at lipidprofilen kan brukes til å identifisere hvem som vil utvikle Alzheimers sykdom (1). Forsøkspersonene ble fulgt i fem år med årlige blodprøver og et stort batteri av tester for å diagnostisere ren hukommelsessvikt. De ble delt i tre grupper på bakgrunn av de psykologiske testene: a) normalgruppen uten fem års hukommelsessvikt, b) begynnende utvikling av en mild amnesi eller Alzheimers sykdom og c) «konvertitter», som initialt var normale, men utviklet hukommelsessvikt i løpet av førsøksperioden.

Sammenliknet med normalkontrollene i gruppe $a$, hadde forsøkspersoner $i$ gruppe $b$ lavere plasmakonsentrasjoner av ti lipidmetabolitter i blodet. Med høy sensitivitet og spesifisitet gikk lipidmønsteret hos «konvertittene» over fra normalt til «Alzheimermønster» allerede 2-3 år før svikt kunne spores med hukommelsestester. 40 plasmaprøver fra nye forsøkspersoner i de tre gruppene ble brukt til å validere funnene.
- Jeg er skeptisk til denne studien, sier professor Nenad Bogdanovic ved Geriatrisk avdeling, Oslo universitetssykehus. - Uten noen arbeidshypotese er hundrevis av lipidom- og metabolommolekyler kvantifisert. Ti lipidmolekyler er valgt ut til nærmere analyse i en relativt liten gruppe forsøkspersoner. Da har forfatterne trolig et statistisk problem. Hvis lipidmønsteret som ble funnet i blodet hos Alzheimerpasientene skulle skyldes nedbrytning av nevroner, ville man ventet økt og ikke nedsatt konsentrasjon av lipidene. Her trenger vi ytterligere og større studier, som også bør inkludere pasienter med frontallappdemens og apopleksi, sier Bogdanovic.

\section{Haakon B. Benestad}

Universitetet i Oslo

Litteratur

1. Mapstone M, Cheema AK, Fiandaca MS et al. Plasma phospholipids identify antecedent memory impairment in older adults. Nat Med 2014; 20: $415-8$

\section{Albumin har ingen fortrinn ved sepsis}

\section{En metaanalyse viste ingen reduksjon i dødelighet ved bruk av humant albumin i sepsisbehandling hos voksne sammenliknet med krystalloider.}

Bruk av albumin i væskebehandling og resuscitering er vanlig, men behandlingen er omdiskutert og det vitenskapelige grunnlaget svakt. Britiske forskere har nylig gjennomført en metaanalyse av randomiserte kliniske studier om effekt og sikkerhet ved bruk av humant albumin ved sepsis hos voksne (1).

Forskerne fant 16 kliniske studier som omfattet 4190 voksne under intensivbehandling for sepsis av ulik alvorlighetsgrad. Median dosering var $70 \mathrm{~g}$ albumin daglig i tre dager, med eller uten korreksjon av hypoalbuminemi. Relativ risiko for død av alle årsaker var omtrent lik i albumingruppene og kontrollgruppene $(0,94$; $95 \%$ KI 0,87-1,01; $p=0,11)$. Det var heller ikke forskjell mellom albuminbehandling og behandling med krystalloider eller syntetiske kolloider.

- Metaanalysen støtter gjeldende retningslinjer, som angir krystalloider til væskeresus- citering ved sepsis, sier stipendiat og lege Knut Anders Mosevoll ved Medisinsk avdeling, Haukeland universitetssykehus. - Dette svekker indikasjonen for bruk av albumin ved sepsis. Det kan likevel ikke utelukkes at undergrupper kan ha nytte av albuminbehandling ved septisk sjokk, noe som dagens retningslinjer åpner for.

- Antallet pasienter i kolloidgruppen var for lavt til å trekke gode konklusjoner, påpeker Mosevoll. Bruk av hydroksyetylstivelse (HES) er fortsatt frarådet $i$ internasjonale retningslinjer på grunn av økt risiko for nyresvikt og økt mortalitet, sier han.

\section{Trine B. Haugen}

Tidsskriftet

\section{Litteratur \\ 1. Randomised trials of human albumin for adults with sepsis: systematic review and meta-analysis with trial sequential analysis of all-cause morta- lity. BMJ 2014; 349: g4850.}

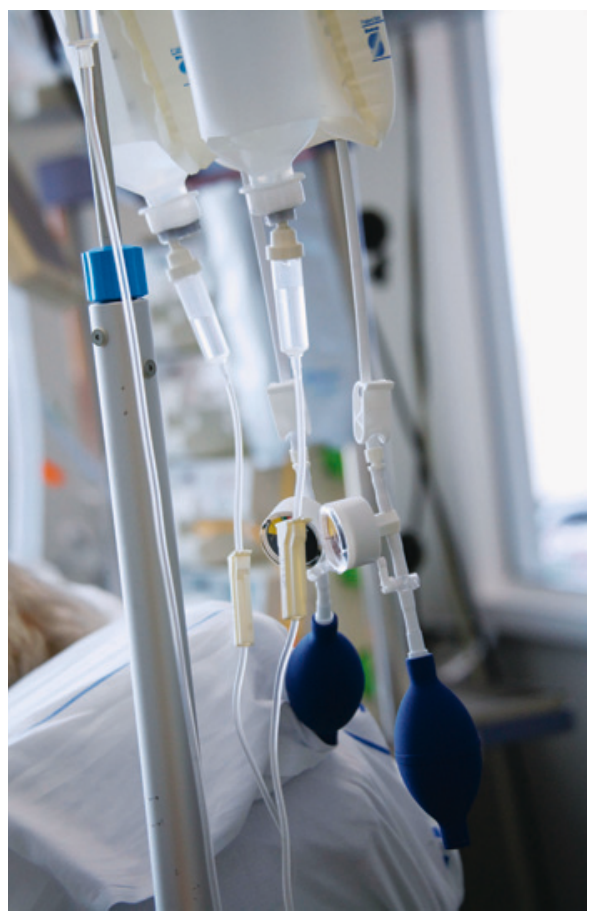

Illustrasjonsfoto: NTB Scanpix 